International Journal of Instruction

e-ISSN: 1308-1470 • www.e-iji.net

Article submission code:

2020051311532

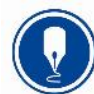

October $2021 \bullet$ Vol.14, No.4

p-ISSN: 1694-609X

pp. $857-872$

Received: 13/05/2020

Revision: 01/05/2021
Accepted: 26/05/2021

OnlineFirst: 02/09/2021

\title{
Linking Administrative Performance of Principals Vis-à-vis Public Relations and Community Involvement
}

\section{Junalyn R. Tadle-Zaragosa}

DepEd Division of El Salvador City, Misamis Oriental, Philippines, junalyn.tadle001@deped.gov.ph

\section{Ramir Philip Jones V. Sonsona}

Teaching Languages and Special Education, University of Science and Technology of Southern Philippines, Cagayan de Oro, Philippines, ramphiljo.sonsona@ustp.edu.ph

Measuring administrative performance aims to determine the effectiveness of school management. For decades, academicians and scholars have not come up with a consensus on this determination including which variables be included. In this study, principals' administrative performance was looked into utilizing Fayol's principles of management and further determining their work attitudes. In retrospect, school principals perform varying roles and functions in the continuous educational process. In order to attain quality education is to have quality school principals. This study investigated the administrative performance of school principals in a progressive school division of El Salvador city, Misamis Oriental, Northern Mindanao, Philippines. Respondents included 15 elementary school principals who rated their management practices and work attitudes. Their answers were validated by the 136 randomly selected teachers who evaluated the administrative performance of the principals. A normative, descriptive method and correlation were employed. A questionnaire determined their administrative performance, including practices and work attitudes. Relevant results revealed scalar chain and security of personnel came out as top management practices of the school heads. Other vital results point to the Environmental attitude of the principals, and teachers' evaluation indicated that the principals manifested above performance rating in the areas of public relations and community involvement. There is a significant relationship between the principals' management practices when correlated with their work attitudes, and this is identified as Fayol's principle of authority. The study recommends that as school managers, principals should foster a good relationship not only with the teachers under their care but also with the parents, and other stakeholders.

Keywords: administrative performance, community involvement, management practices, public relations, school leadership, school principals 


\section{INTRODUCTION}

Mohammed, Edu \& Etoh (2020) clearly elucidated that the effective performance of any system largely depends on the nature of its administrative setup as well as control. The realization of goals and objectives of an enterprise cannot be entirely suspended from its administrative skills and competence. In this aspect, they further contended that the school principal who stands at the epicentre of all activities is saddled with so many tasks to perform, ranging from effective delegation of authorities, to staff training and students' management as well as students' performance management.

This study has looked into the administrative functions of a school principal and how his functions, work attitudes would be aligned to that of Fayol's principles of management. And considering that to be an effective school principal is never an easy task. Hence this study was conceptualized, for a school principal has to embrace leadership, student discipline and guardianship, teacher training, evaluation, and other related functions. Being a competent school principal entails a lot of hard work and dedication. Meador (2019) attested that good school principals functioned by balancing their roles and responsibilities in ensuring that they are doing what they think and ought to be the best for all constituents in the school environment. In effect, school principals are anticipated to be efficient at performing their management practices, which include organizing, staffing, scheduling, and prioritizing. It is in this aspect that their esteemed leadership is the key to success for schools. Leadership not only sets the stage for long-term achievement, but it ensures long-term sustainability. Earley (2013) manifested that in a school setting, a leader must be multifaceted as they need to interact with many stakeholders but not constricted to teachers, students, parents, support staff, and others.

Moreover, the school principal must be responsible for encouraging and stimulating activities that will help the teachers improve the teaching-learning situation; a leader is a driving force behind organizational development. Leadership is a factor in good management. It is the elusive quality of management that inspires others to perform. Relatedly, the principal is entrusted with the responsibility of improving the quality of administration and instructional activities through effective use of various practices to influence the teachers in carrying out their respective duties for enhanced productivity and quality output (Nwabueze, Chukwuji \& Ugwoezuonu, 2018). Several research findings indicate that there is a significant relationship between the components of principals' leadership behaviors and teachers' sense of self-efficacy (Mehdinezhad \& Mansouri, 2016).

The school principals in the Division of El Salvador City, Northern Philippines, occupy an essential position in the educational system; their responsibility pertains to the efficient and effective administration and management of the organization, most especially that their school division is a newly created one under Republic Act No. 9435. This is done through prudent planning, organizing, directing, communicating, and coordinating the efforts of personnel in the organization. They determine the allocation of resources to achieve the goal efficiently and effectively. As a school principal and leader, he/she should be the person who can motivate a group of people to accomplish 
the task and maintain team unity throughout the process. Consequently, as a leader, one must possess the capability to inspire others to follow his lead.

The present study would serve as a basis for improvement geared toward the welfare of the school principals as they go through their multifaceted administrative and management functions. Moreover, results would be a point of reference for those who were involved in the management of an institution. School principals would be given help in line with their leadership and managerial functions because it stimulated dedication in the fulfillment of their tasks.

\section{Theoretical Framework and Related Readings}

The theoretical background of this study was anchored from the theories developed by Fayol. He developed a general theory relating to the organization, administration, and management. As cited by Bacud (2020), Fayol's various management principles are still being followed today in the management concepts and principles. As these constituted considerably good management practice, and proposed a universal set of management functions, which were fundamental management principles in the workplace.

Moreover, Poperwi (2018) stated that Henri Fayol enunciated the fourteen principles of management for the efficient running of businesses but it is said that these principles are flexible and is capable of adaptation depending on the specific need of the organization. In this aspect, personnel management comes in as the task of handling the problem arising from the different relationships of the school staff, such as the appointing, supervising, and dismissing of teachers, principals, and other employees of a school system (Sammons et al., 2011).

This study adheres to the application of Fayol's management into the principal's administrative performance. Garba (2017) testified that the effective implementation of the principles is considered to have a positive influence on the management of education. Bacud (2020) in her study concluded that management principles enunciated by Henri Fayol are still widely adopted and applicable today and claimed to have been significant in attaining successful governance.

\section{Multifaceted roles of a School Principal}

Schools principals require extraordinary traits, attitudes, and behavior in order to attain a strong image. True to this, Adeyemi (2011) attested that among the many roles of a school principal include providing effective leadership, maintaining the welfare of teachers and managing instructional facilities in secondary schools through which the job performance of teachers and principals can be enhanced.

The school leader's goal is to promote the teaching-learning process. A leader should see to it that quality education is offered and maintained. However, over the years, the deteriorating quality of education in the country has been more apparent (Robbins, Coulter \& Vohra, 2010). 


\section{Work Attitudes and Performance}

A person's work attitudes may determine, to a large degree, what he does or how well he performs. The presence of strong incompatible attitude and those of others may affect his efficiency and personal adjustment (Kafele, 2014). As observed, employees who are in a positive, encouraging work attitudes, of management are more likely passionate and remain dedicated. Good performance cannot be secured by remote control, by executive orders, or by written instructions. It will only exist when men and leaders are working together, and when their thoughts are running in similar channels (Anderson \& Turnbull, 2016).

The effective performance of any system largely depends on the nature of its administrative setup as well as control. The realization of goals and objectives of an enterprise cannot be entirely suspended from its administrative skills and competence (Mohammed, Edu, \& Etoh, 2020). Performance appraisal is essential for it helps the school principals discover the direction in which improvement is desirable. Thus, evaluation is not an end but a means of discovering the need for change and the direction in which the change will progress. From the management point of view, an appraisal is necessary to allocate resources in a dynamic environment, reward employment, give employees feedback about their work, maintain a good relationship with groups, coach and develop employees and comply with an equal opportunity to regulations (Stronge, 2013).

A school principal's evaluation of himself is not a sufficient index of the actual performance of his assigned tasks. Merit should be given, likewise, to the assessments made by important persons he comes in contact with. He/she needs especially the appraisal made by his superintendent, by his administrative and supervisory worker, his teaching staff, and by the pupils and their parents

\section{Problem}

This study aimed to find out the school principals' administrative performance in the Division of El Salvador City, Misamis, Oriental, Philippines. Mainly, this study sought to answer the following questions (RQ1) What is Fayol's dominant management practices of the school principal in terms of Authority, Unity of Command and Direction, Remuneration, Discipline, Initiative, Subordination of Individual Interest to General Interest, Centralization, Scalar Chain, Order, Stability of Tenure of Personnel, and Esprit de Corps? (RQ2) What are the work attitudes of principals when classified according to Environmental, Familial, Intellectual, and Material? (RQ3) What is the level of administrative performance as perceived by teachers, with regards to principals: 1) Utilization Planning and Organizing Work; 2) Utilization and Allocation of Resources; 3) Promptness/Accuracy in Submission of Required Reports, Statistics and Budget Proposals; 4) Problem Analysis and Decision Making; 5) Leadership and Personnel Management, and 6) Public Relations and Community Involvement? (RQ4) Is there a significant relationship between the principals' work attitudes and management practices? 


\section{METHOD}

This research study has utilized a descriptive method. In this process, correlation and interview were also employed. In ascertaining the school principals' management and work attitudes, descriptive-normative method was used. While correlation was done to find out the relationship of school heads' management practices, work attitudes and management practices. And interview and a Focus Group Discussion (FGD) were employed to gather the best practices of each school principal based on their management practices and work attitudes. Survey questionnaires namely Fayol's principles of management and the school's principals' work attitudes were used to obtain the needed data.

The respondents of the study comprised of two groups, the 15 public elementary school principals and randomly selected elementary teachers in the Division of El Salvador City. One hundred thirty-six public elementary teachers were randomly selected from a total of 210. By using Cochran's sample size formula, with a 5\% margin of error and a 95\% level of confidence, the number of respondents was determined. The school principals rated their management practices and work attitudes while the teachers evaluated their principals' administrative performance.

For the validity and reliability, the survey instrument was pre-tested for validity to teachers in another school division, which was not part of the study. Cronbach alpha was used for the survey instrument of the principal's management practices. The test assessed the reliability or internal consistency of the pre-tested questionnaire. It obtained a reliability index of 0.978 , which was deemed valid.

\section{FINDINGS AND DISCUSSION}

Problem 1 (RQ1) What is Fayol's dominant management practices of the school principal in terms of Authority, Unity of Command and Direction, Remuneration, Discipline, Initiative, Subordination of Individual Interest to General Interest, Centralization, Scalar Chain, Order, Stability of Tenure of Personnel, and Esprit de Corps? 
Table 1

Mean values of perceived dominant management practices of school principals

\begin{tabular}{llll}
\hline Principles of Management & Mean & Verbal Description & Interpretation \\
\hline Division of Work and Equity & 4.26 & At all Times & Extremely Dominant \\
\hline Authority & 4.36 & At all Times & Extremely Dominant \\
\hline Discipline & 4.48 & At all Times & Extremely Dominant \\
\hline Unity of Command and Direction & 4.21 & At all Times & Extremely Dominant \\
\hline $\begin{array}{l}\text { Subordination of Individual } \\
\text { Interest to General Interest }\end{array}$ & 4.40 & At all Times & Extremely Dominant \\
\hline Remuneration & 4.26 & At all Times & Extremely Dominant \\
\hline Centralization & 4.28 & At all Times & Extremely Dominant \\
\hline Scalar Chain & 4.52 & At all Times & Extremely Dominant \\
\hline Order & 4.14 & Most of the Time & Very Dominant \\
\hline Stability of Tenure of Personnel & 4.52 & At all Times & Extremely Dominant \\
\hline Initiative & 4.26 & At all Times & Extremely Dominant \\
\hline Esprit de Corps & 4.42 & At all Times & Extremely Dominant \\
\hline
\end{tabular}

Table 1 presents the 12 management practices that were rated by the school principals. As can be inferred, almost all of the management practices based on principles developed by Fayol were extremely dominant at all times. The management practices on the scalar chain and stability of tenure were rated highest among the 12 selected principles with the same mean score of 4.52, while the management practices on order (4.14), which is a notch lower but is still a reasonable manifestation of effective management. Data infer that teachers are well informed about issues and concerns of the school at all times. As a result, school principals were respected as the immediate authority, so clear and systematic communication of the school principal is easily facilitated along the different channels of authority.

The above results were supported by Aman et al. (2012) when they specified that there are structural principles that describe the methods and guidelines of organizational structure through the scalar chain, authority, responsibility, centralization, unity of direction, and division of labor (tasks). Similarly, the findings of Mbalamula, Suru \& Seni (2017) manifested that these process principles determine the ongoing activities of the organization through subordination of individual interest, equity, remuneration, unity of command and discipline in the administration of organizations. Likewise, the stated principles disclosed the basic objectives and goals of organization trough esprit de corps, initiative, stability of tenure and order in the administration of organizations.

Through this, Fayol believed that there should be constant communication between supervisors and employees. As such, teachers should feel free to contact his principal about any request, instruction, or explanation. More so, the satisfaction of the teachers should be given significance by the principle that Fayol refers to as stability of tenure; this can develop a sense of belongingness toward the organization and improve the efficiency level of the teachers because they feel satisfied and thus become a productive factor for the organization. Principals' supervisory, leadership and communication 
competences are significantly related to teachers' work performance in terms of instructional delivery and other key functions (Owan \& Agunwa, 2019).

Problem 2 (RQ2) What are the work attitudes of principals when classified according to Environmental, Familial, Intellectual, and Material?

Table 2

Mean values of perceived work attitudes of school principals

\begin{tabular}{llll}
\hline Work attitudes & Mean & Verbal Description & Interpretation \\
\hline Environmental & 4.12 & Most of the Time & Good Practiced \\
\hline Familial & 3.64 & Most of the Time & Good Practiced \\
\hline Intellectual & 3.86 & Most of the Time & Good Practiced \\
\hline Material & 3.93 & Most of the Time & Good Practiced \\
\hline \multicolumn{1}{c}{ Total Mean } & 3.89 & Most of the Time & Good Practiced \\
\hline
\end{tabular}

Table 2 reveals the information on the school principals work attitudes, which were rated by the school principals themselves. The work attitudes of school principals were analyzed in terms of environmental, familial, intellectual, and material aspects. Data indicated that all the aspects were practiced at all times. Among the four aspects, environmental concern was rated highest, primarily pointing to principals' directives, which include the prohibition of smoking inside their office and attending to leaking drainage pipe that contributes to an environmental hazard.

Findings also attested that the school principals were primarily concerned with the physical condition and environment of the school premise. The environment of a school is a critical factor in the overall health and safety of students, staff, and visitors. Several studies have shown that student achievement can be affected either by the school environment.

Moreover, in accordance with the Sustainable Development Goals (SDGs), which is, Ensure inclusive and equitable quality education and promote lifelong learning opportunities for all, Garcia-Feijoo, Eizaguirre, \& Rica-Aspiunza (2020) elucidated that in order to attain this, the need for adequate physical infrastructure and safe, inclusive environments that nurture learning for all, regardless of background or disability status is being done by the school principals' in their own work places. Schools have to play in achieving SDGs and the ways in which they can be incorporated into their activity which includes fostering cooperation and interdisciplinarity with stakeholders, and working on coherence just to enumerate a few.

On the same stance, Makewa, Role \& Yegoh (2011) stipulated that a healthy environment in the school can greatly help a child in making social adjustment; school climate was found out to have a significant influence on the academic performance of the students. In this perspective, the school environment is the extent to which student safety and student health are supported by school settings and may include aspects as the physical plant, the academic environment, availability of supports and services for promoting the well-being of students and provision of fair and adequate disciplinary rules and regulations (Narad \& Abdullah, 2016; Lawrence \& Avimala, 2012; Zais, 2011). In the same, principals should act ethically, morally, professionally, responsibly, 
practically, and critically so as to accommodate professional need of the nation to bring about behavioral changes and to attain quality education (Gobena, 2017).

Problem 3 (RQ3) What is the level of administrative performance as perceived by teachers, with regards to principals: 1) Utilization Planning and Organizing Work; 2) Utilization and Allocation of Resources; 3) Promptness/Accuracy in Submission of Required Reports, Statistics and Budget Proposals; 4) Problem Analysis and Decision Making; 5) Leadership and Personnel Management, and 6) Public Relations and Community Involvement?

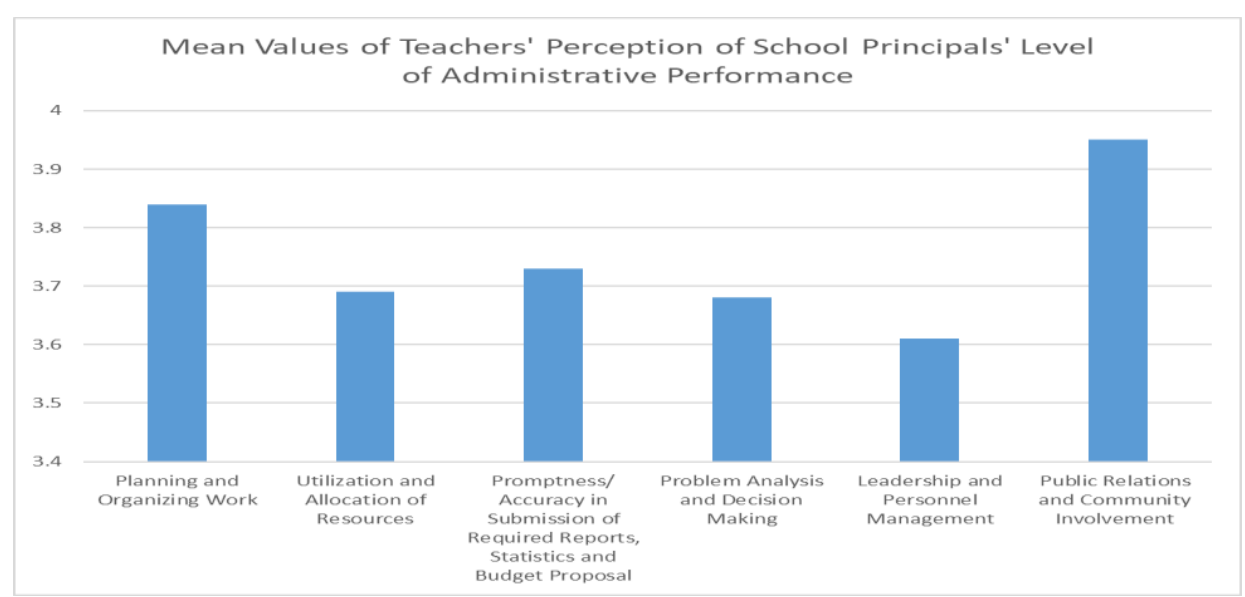

Figure 1

Presents the school principals' administrative performance

The above figure showcases the graphical presentation on the six areas of the principals' administrative performance. Public Relations and Community Involvement (3.95) ranked first and followed by Planning and Organizing Work (3.84) and Promptness/Accuracy in the submission of required reports, statistics, and budget proposals (3.73). Numerous studies and academicians have supported these results. Bacud (2020) testified that there is now a high regard to a collaborative governance, that is making all other sectors work together for a common goal. Government, community, and civil society work as one to achieve performance in organization.

Relatedly, Maier, Daniel, Oakes \& Lam (2017) indicated that the meaningful family and community engagement found in community schools is associated with positive student outcomes, such as reduced absenteeism, improved academic outcomes, and student reports of more positive school climates. Additionally, this engagement can increase trust among students, parents, and staff, which has positive effects on student outcomes.

Thus, the principal must mount strategies to establish good school-community relations. For many principals engaging in school-community involvement requires participation in relationship development and maintenance tasks that can, at times, take them away 
from direct school functions (Hauseman, Pollocok \& Wan, 2017; Sanders, 2014 ,). Building strong ties with the community would yield positive results as family and community engagement tends to have its most direct effects on creating conditions for learning, such as increased trust, the impact on student outcomes is often indirect (Bryk, Sebring, Allensworth, Luppescu, \& Easton, 2010).

Tamen (2011) recognized the importance of participation and involvement; community and its educational leaders cooperate in planning, formulating policy, and implementing school programs. There is a good reason for seeking close integration of community and school. Meador (2016) claimed that in a school setting, a leader must be multifaceted as they deal with other school principals, teachers, support staff, students, and parents. In effect, school principals are the most responsible persons for the efficiency and effectiveness of school supervision and management. They are the most proper persons to give and offer assistance, support, motivation, and supervision in making the teachers more dedicated, inspired and committed to teaching because they are in contact with teachers. Connectedly, Samoei's study (2014) found out that principals and headteachers' were skilled in administrative planning, organizing people and resources, human relations, and public relations. They were less skilled in directing and in controlling. Significant differences between the principals and teachers were found in administrative planning, controlling, and decision-making.

(RQ4) Is there a significant relationship between the principals' work attitudes and management practices?

Table 3

Pearson's correlation test for management practices against school principals' work attitudes

\begin{tabular}{lllll}
\hline \multicolumn{1}{|l}{ Indicators } & $\begin{array}{l}\text { Pearson's } \\
\text { rho }\end{array}$ & $\begin{array}{l}\text { P- } \\
\text { value }\end{array}$ & $\begin{array}{l}\text { Decision on } \\
\text { Ho }\end{array}$ & Interpretation \\
\hline Division of work & -0.071 & 0.802 & Not rejected & Not significant \\
\hline Authority & $0.525^{*}$ & 0.044 & Rejected & Significant \\
\hline Discipline & 0.148 & 0.60 & Not rejected & Not significant \\
\hline Unity of Command Direction & 0.293 & 0.325 & Not rejected & Not significant \\
\hline $\begin{array}{l}\text { Subordination of Individual to } \\
\text { General Interest }\end{array}$ & 0.293 & 0.289 & Not rejected & Not significant \\
\hline Remuneration & 0.446 & 0.096 & Not rejected & Not significant \\
\hline Centralization & 0.350 & 0.201 & Not rejected & Not significant \\
\hline Scalar Chain & 0.198 & 0.48 & Not rejected & Not significant \\
\hline Order & 0.403 & 0.136 & Not rejected & Not significant \\
\hline Stability of Tenure of Personnel & -0.049 & 0.862 & Not rejected & Not significant \\
\hline Initiative & 0.301 & 0.276 & Not rejected & Not significant \\
\hline Esprit de Corps & -0.323 & 0.241 & Not rejected & Not significant \\
\hline *Significant at 0.05 level & & & &
\end{tabular}

Table 3 showcases the result of a Pearson correlation analysis between the school principals' management practices based on Fayol's principles and each of specific aspect which determines the school principals' work attitude, namely, environmental, 
familial, intellectual and material. Data reveal that there is no sufficient evidence to reject the null hypothesis in all pairs of work attitudes with management practices. Furthermore, data also showed that only the school principals' authority yielded sufficient evidence to reject the null hypothesis against a 0.05 level of significance. These findings indicated that there is a significant relationship between the school principals' authority and work attitudes $(\mathrm{r}=0.525)$. Results confirm to that study of Garba (2017) that authority yielded a positive relationship; it supported the idea that the administrative head of the school must have the authority to give orders, but she or she must also keep in mind that with authority comes responsibility.

Evidence to this, school principals can play a vital role in enhancing teacher leadership through delegating authority and empowering teachers in ways that allow them to influence organizational processes and decisions (Sebastain \& Allenworth, 2016). Generally, school principals with the competent authority in school possessed good work attitudes, and those with inadequate authority in school exhibit less-than-superior work attitudes. Fayol opined that management has the right to give orders to the subordinates. This delegation of authority as opined by Achinivu, Handsome, Ayomide, Enobong, \& Johnson (2017) suggested that there is a necessity for managers to possess authority in order to direct subordinates so they can do their jobs while taking responsibility for their actions. Sebastain \& Allenworth (2016) added that the principal's delegation of authority and responsibility would empower teachers and school personnel, which also involves others in setting schools' direction and organizing their daily operations. And the push for more exceptional teacher leadership has gained traction in school organizational research and policy. This has gained support in the concepts espoused by Hamid, Shah, Rahman \& Badlishah (2020) as leadership significantly affects an individual and organizational interaction. Significantly, a great leader must not only encourage potential subordinate to improve efficiency, but also sees to it that their needs are met in the process of achieving organizational goals.

Authority has been considered as the right of principals to give orders and power to maintain discipline while responsibility is the obligation of teachers to obey and comply with the instructions and directives given. Fayol believed that authority and responsibility go together. Whenever authority is exercised, responsibility arises. So there needs to be a proper balance between authority and responsibility (Bacud, 2020, Hamid et al, 2020; Mbalamula, Suru \& Seni, 2017; Achinuvu et al. 2017; Pryor \& Taneja, 2010). In consonance, Ismail and Hapsoro (2020) claims that authority is the power of a certain group of people or power over a certain spherical sector of government (or field of affairs).

The study found out that the scalar chain and security of personnel came out as top management practices of the school heads. Other vital results point to the Environmental attitude of the principals, and teachers' evaluation indicated that the principals manifested above performance rating in the areas of public relations and community involvement. Fayol's authority principle yielded a significant relationship when principals' management practices were correlated with their work attitudes. 
In congruence, school principals' performance as evaluated by their teachers on the six areas is above performance across all areas. The rating for Public Relations and community involvement found out to be the highest as boosted by specific indicators that inform parents and the community about the activities of the school and define or clarify the role of teachers, parents, community leaders, and students concerning the educational programs of the school. Also, the school principals' support subordinates in terms of advice, ideas, structure, or process for more useful output. As true to this, school principals should be ready to offer information and ideas when the teachers need such help. Tanzeh (2019) postulated that a school's success is determined not only by principals and teachers but also greatly influenced by the principal through managerial capability in creating high teacher morale, among other factors. This developing push for schools and community engagement has yield to the idea that strong research reinforces the efficacy of integrated student supports, expanded learning time and opportunities, and family and community engagement as intervention strategies (Maier, Daniel, Oakes \& Lam (2017) Hence, creating a good relationship with the community is a must in this regard.

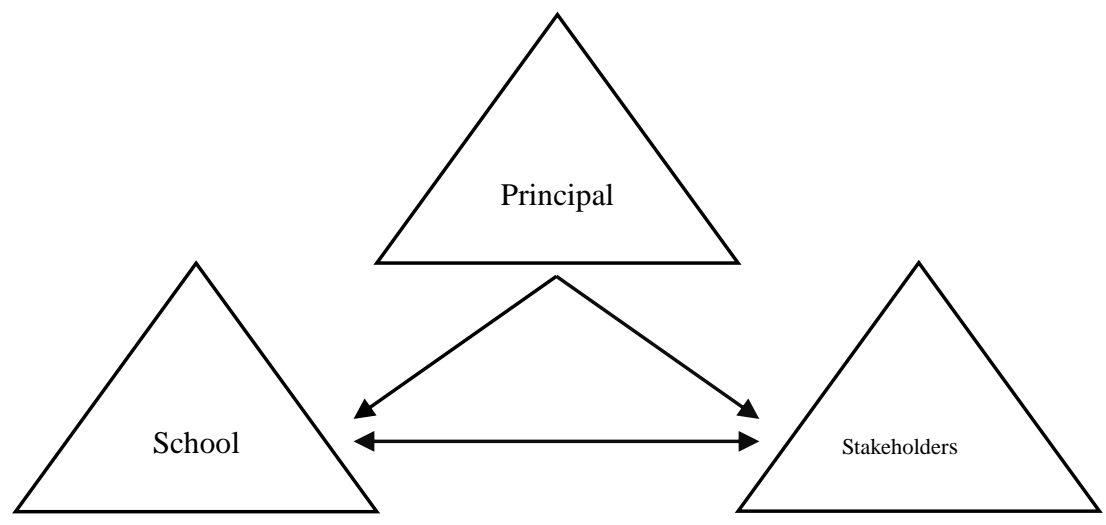

Figure 2

The diagram above displays the relationship derived in this study

The above diagram shows this researcher's conceptualization of the variables involved in this study. School principals have a significant role in bridging the gap between the schools and the various stakeholders, such as the Parent Teachers Association (PTA), socio-economic leaders, businessmen, alumni, church leaders, and the like. Akin to this, Nakpodia (2011) claimed that the formal way of maintaining contact with the community is through the PTA, and the principal in such a relationship is a critical person in bringing about enthusiasm and zeal in community support for the school to meet with the emerging design of education. Fostering a good relationship with them will give suitable fruition in the educational landscape of the school. Banda (2019) espoused that school-community through parental involvement in education today is considered as the back bone of any education system; well established community and 
government schools should be giving assistance to such schools in order to improve the delivery of education.

This paper supports the theory of Epstein's six types of parental involvement (parenting, communicating, volunteering, learning at home, decision-making, and collaborating with the community). Parent involvement has an influence on children's educational engagement during the elementary years (Banda, 2019; Erdener \& Knoeppel, 2018). Moreover, Banda's study (2019) suggested that in school settings a cordial relationship between school and community, increased awareness of school activities can yield toward increased students' performance.

Also, school administrators must show the highest level of integrity to the various leaders of socio-civic agencies and the members of the public, including parents, religious leaders, and sustenance of a communal organizations. Productive school managers should be involved in developing and implementing the necessary skills to bolster the best teaching and learning environment. The ever-changing needs of the school institution stem out of the never-ending pressure from the different stakeholders in the educational organization. The capacity to perform both as leaders and managers shape the school organization as a whole (Canivel, 2010).

Successful and effective school leaders collaborate with the concerned stakeholders in identifying, and setting goals aligned with school's vision and in return government should provide adequate funding to these schools, collaborate with Parent Teacher Association (PTA) and other private sectors in supporting such schools and make available teaching and learning resources in order to make teaching and learning possible (Banda, 2019; Maier, Daniel, Oakes \& Lam, 2017; Nakpodia, 2011).

The development and maintenance of dynamic and harmonious relations are essential in all organizations. Cruz et al. (2016) recommends in their study the establishment of school and community networks through encouraging the active participation of all of the stakeholders. Hence, there should be an involvement of the stakeholders in planning, monitoring, and evaluating the progress the school has set. Likewise, membership in community organizations is desirable for any school administrator. Service clubs, fraternal orders, business and professional organizations, church, and civic improvement bodies are examples of organizations where membership is profitable in terms of better school-community relationships. Membership in the local organizations provides opportunities for acquiring community background essential to the effective management of the school (Harris \& Jones, 2010).

\section{CONCLUSION AND RECOMMENDATIONS}

The study deduced that Fayol's principles of the scalar chain, the security of personnel, and authority are evident in the school setting. The school principals and the schools can use these tools in planning, forecasting, process management, organization management, decision-making, coordination, and control. Also, principals' work attitudes are identified as environmental and teachers' evaluation of school principals showed above performance rating in the areas of public relations, and community involvement. The findings also disclose that school principals are consultative, and participative in the 
formulation of goals, methods, and activities of the school, and they have adequately executed their tasks and functions, such as delegating authority and empowering teachers in ways that allow them to influence in crucial organizational processes and decisions. Correspondingly, school principals should have a good relationship with the public and community who are able and supportive of the programs and activities of the school. Generally, a school cannot exist if it cannot avail of the services of the community as a partner in the educational system. School principals, who are responsible for education, must keep the human bond, for it brings a strong relationship that could manifest the striking advancement for the attainment of the school's goals.

In the light of the findings and conclusions, the following recommendations were manifested principals should continue to have good relations with parents, community members (business people, church leaders, alumni, other stakeholders) for this relationship with them can help their school tremendously. As school managers, school principals should have strong coordination and cooperation between teachers. Even more so, constant communication among parties involved and revisions of plans are necessary. Superintendent/Education program supervisors should have a periodic selfevaluation to the elementary school principals, and their subordinates to continually remind them of their tasks/functions and also to facilitate identification of their strengths and correction of their weaknesses. The study was limited to the application of Fayol's principles of management employed by the school principals in their administrative functions, hence other variables not included may be explored in another research undertakings.

\section{REFERENCES}

Achinivu, G., Handsome, O.E., Ayomide, W.A., Enobong, A. E. \& Johnson, F.O. (2017). Application of the Henri Fayol principles of management in startup organizations, IOSR Journal of Business and Management (IOSR-JBM), 19(10), 78-85.

Adeyemi, T. O. (2011). Principals' leadership styles and teacher's job performance in senior secondary schools in Ondo State, Nigeria. Ado-Ekiti: University of Ado-Ekiti Press.

Anderson, L. \& Turnbull, B. (2016). Evaluating and Supporting Principals. Building a stronger Principalship, Volume 4. Policy Studies Associates, Inc., The Wallace Foundation.

Bacud, S. (2020). Henri Fayol's Principles of Management and its effect to Organizational Leadership and Governance. Journal of Critical Reviews, 7(11), 162167.

Bryk, A. S., Sebring, P. B., Allensworth, E., Luppescu, S., \& Easton, J. Q. (2010). Organizing Schools for Improvement: Lessons from Chicago. Chicago, IL: University of Chicago Press.

Canivel, L. D. (2010), Principals' Adversity Quotient: Style, Performance and, Practices (Unpublished master's thesis, University of the Philippines, Philippines). 
Retrievedfrom:https://www.peaklearning.com/wpcontent/uploads/2019/05/PEAK_GRI_ canivel.pdf

Cruz, Villena, Navarro, Belecina, \& Garvida (2016). Towards Enhancing the Managerial Performance of School Heads. International Review of Management and Business Research, 5(2), 705-714.

Earley, P. (2013). Exploring the school leadership landscape: Changing demands, changing realities. London: Bloomsbury.

Erdener, M. A., \& Knoeppel, R. C. (2018). Parents' Perceptions of Their Involvement in Schooling. International Journal of Research in Education and Science, 4(1), 1-13.

Garba, M. A. (2017). Application of Henri Fayol's managerial principles in Nigerian secondary schools: Stakeholders' perceptions. International Journal for Innovative Research in Multidisciplinary Field, 3(10), 114-124.

Garcia-Feijoo, Eizaguirre, \& Rica-Aspiunza (2020). Systematic Review of SustainableDevelopment-Goal deployment in Business Schools. Education and Sustainable Development, Sustainability, 12(1), 440.

Gobena, G. (2017). Attitude of School Principals, Supervisors and Mentees towards Action Research as Reflective Practices, International Journal of Instruction, 10(1), 120.

Hamid, K. A., Shah, S. M. M., Rahman, N. I. A \& Badlishah, S. (2020). The moderating impact of performance appraisal politics on leadership styles and job performance: overview from banking sector in Pakistan, Journal of Critical Reviews, 7(5), 183-189.

Harris, A. \& Jones, M. (2010). Professional learning communities and system improvement. Improving Schools, 13(2), 172-181.

Hauseman, D. C, Pollock, K. \& Wang (2017). Inconvenient, but Essential: Impact and Influence of School-Community Involvement on Principals' Work and Workload, School and Community Journal, 27(1), 83-105.

Ismail \& Hapsoro, F. (2020). The authority of the corruption eradication commission in the Prosecution of corruption in Indonesia, Journal of Critical Reviews, 7(5), 177-182.

Kafele, K. (2014). The principal 50.: critical leadership questions for inspiring schoolwide excellence. ASCD Books, Inc.

Lawrence, A. S. A., \& Vimala, A. (2012). School environment and academic achievement of standard ix students. Journal of Educational and Instructional Studies, 2(3), 210-215.

Makewa, L.N., Role, E. \& Yegoh, E. (2011). School Climate and Academic Performance in High and Low Achieving Schools: Nandi Central District, Kenya. International Journal of Scientific Research in Education, 4, 93-104. 
Maier, A., Daniel, J., Oakes, J., \& Lam, L. (2017). Community schools as an effective school improvement strategy: A review of the evidence. Palo Alto, CA: Learning Policy Institute.

Mbalamula, Y., Suru, M. \& Seni, M. (2017). Utility of Henri Fayol's Fourteen Principles in the Administration Process of Secondary Schools in Tanzania. International Journal of Education and Research, 5(6), 103-116.

Meador, D. (2019). The role of principals in schools. Retrieved from: https://www.thoughtco.com/role-of-principal-in-schools-3194583

Meador, D. (2016). The essential qualities of an effective school leader. Retrieved from: https://www.thoughtco.com/how-school-administrator-can-be-effective-leader-3194569

Mohammed M.O.B, Edu A.O. and Etoh L.C. (2020). Principals' Administrative Skills: A Predictor of Students' Academic Performance in Lagos State, Nigeria. Journal of Research in Educational and Business Studies, 5(1), 186-203.

Owan, V \& Agunwa, J. (2019). Principals' Administrative Competence and Teachers' Work Performance in Secondary Schools in Calabar Education Zone of Cross River State, Nigeria. Humanities and Social Sciences Letters, 7(1), 20-28.

Nakpodia, E. D. (2011). Community Involvement in the Management of Secondary Schools in Delta Central Senatorial District Nigeria. United Kingdom: Social Science Research Network Sheffield University.

Narad, A. \& Abdullah, B. (2016). Academic Performance of Senior Secondary School Students: Influence of Parental Encouragement and School Environment. Rupkatha Journal on Interdisciplinary Studies in Humanities, VIII(2), 12-19.

Nwabueze, A. I., Chukwuji, C. E \& Ugwoezuonu, A. U. (2018). Perceived impact of principals' leadership skills on teachers'functional performance and students' study habits in secondary schools in Enugu State. Nigeria Journal of Educational Administration and Planning (NJEAP), 17(1), 48-66

Pryor, M. G., \& Taneja, S. (2010). Henri Fayol, practitioner and theoretician - revered and reviled. Journal of Management History, 16(4), 489-503.

Robbins, S. P., Coulter, M., \& Vohra, N. (2010). Management, New Delhi, Dorling Kindersley.

Sammons, P., Gu Q., Day C., \& Ko J. (2011). Exploring the impact of school leadership on pupil outcomes. International Journal of Educational Management, 25(1), 83-101.

Samoei, C. (2014). Instructional supervisory role of principals and its influence on students' academic achievement in public secondary schools in Nandi North district Nandi County Kenya. (Unpublished master's thesis, Catholic University of Eastern Africa). $\quad$ Retrieved from: http://ir.cuea.edu/jspui/bitstream/1/115/1/CatherinesThesis\%201018461.pdf 
Sebastain, J. \& Allenworth, E. (2016). The Role of Teacher Leadership in How Principals Influence Classroom Instruction and Student Learning. American Journal of Education, 123(1), 69-108.

Tamen, R. (2011). Professional learning communities: A bandwagon, an idea worth considering, or our best hope for high levels of learning? In E. B. Hilty (Ed.), Teacher leadership: The "new" foundations of teacher education. NY: Peter Lang Publishing, Inc.

Tanzeh, A. (2019). The Correlation between the effectiveness of School Quality Planning, Capacity of Organizing personnel, and Teacher's work motivation. Malaysian Online Journal of Educational Management (MOJEM), 7(4), 82-105.

Zais, M. (2011). South Carolina School Environment Initiative. Columbia: South Carolina Department of Education. Retrieved from: http:ed.sc.gov/agency/ac/StudentInterventionservices/documents/SCSchoolEnvoronmne tRFP-Nov2011.pdf 